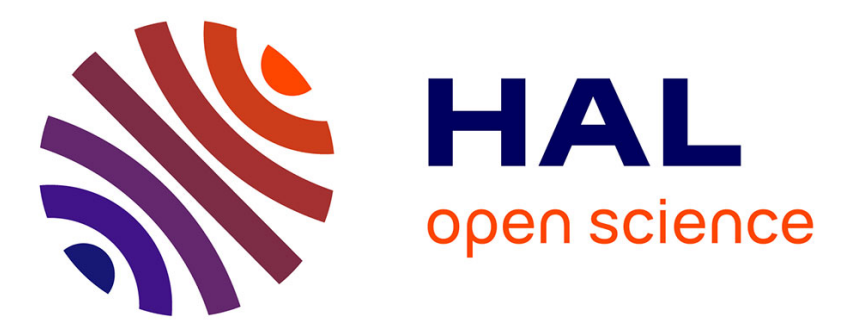

\title{
Mastering demand and supply uncertainty with combined product and process configuration
}

\author{
C.N. Verdouw, A.J.M. Beulens, J.H. Trienekens, T. Verwaart
}

\section{To cite this version:}

C.N. Verdouw, A.J.M. Beulens, J.H. Trienekens, T. Verwaart. Mastering demand and supply uncertainty with combined product and process configuration. International Journal of Computer Integrated Manufacturing, 2010, 23 (06), pp.515-528. 10.1080/09511921003667706 . hal-00594818

\section{HAL Id: hal-00594818 \\ https://hal.science/hal-00594818}

Submitted on 21 May 2011

HAL is a multi-disciplinary open access archive for the deposit and dissemination of scientific research documents, whether they are published or not. The documents may come from teaching and research institutions in France or abroad, or from public or private research centers.
L'archive ouverte pluridisciplinaire HAL, est destinée au dépôt et à la diffusion de documents scientifiques de niveau recherche, publiés ou non, émanant des établissements d'enseignement et de recherche français ou étrangers, des laboratoires publics ou privés. 


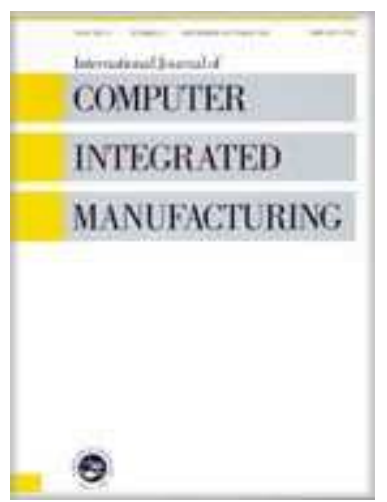

\section{Mastering demand and supply uncertainty with combined product and process configuration}

\begin{tabular}{|c|c|}
\hline Journal: & International Journal of Computer Integrated Manufacturing \\
\hline Manuscript ID: & TCIM-2009-IJCIM-0068.R1 \\
\hline Manuscript Type: & Original Manuscript \\
\hline $\begin{array}{l}\text { Date Submitted by the } \\
\text { Author: }\end{array}$ & $15-J a n-2010$ \\
\hline Complete List of Authors: & $\begin{array}{l}\text { Verdouw, C.N.; LEI Wageningen UR } \\
\text { Beulens, A.J.M.; Wageningen University, Logistics, Decision and } \\
\text { Information Sciences Group } \\
\text { Trienekens, J.H.; Wageningen University, Management Studies } \\
\text { Group } \\
\text { Verwaart, T.; LEI Wageningen UR }\end{array}$ \\
\hline Keywords: & $\begin{array}{l}\text { SUPPLY CHAIN MANAGEMENT, MASS CUSTOMIZATION, } \\
\text { CONCURRENT ENGINEERING, ERP }\end{array}$ \\
\hline Keywords (user): & CONFIGURATION, FLOWER INDUSTRY \\
\hline
\end{tabular}

\section{ScholarONE" \\ Manuscript Central}


Mastering demand and supply_uncertainty with combined product and process configuration,

\author{
C.N. Verdouw ${ }^{\mathrm{a}}{ }^{*}$, A.J.M. Beulens ${ }^{\mathrm{b}}$, J.H. Trienekens $^{\mathrm{c}}$, T. Verwaart $^{\mathrm{a}}$ \\ a LEI Wageningen UR, Wageningen, The Netherlands \\ $b$ Logistics, Decision and Information Sciences Group, Wageningen University, \\ Wageningen, The Netherlands \\ c Management Studies Group, Wageningen University, Wageningen, The Netherlands
}

Full correspondence details corresponding author:

Cor Verdouw

LEI Wageningen UR

P.O. Box 35

6700 AA Wageningen

The Netherlands

Phone: +31-317-484752

Fax: +31-70-3615624

e-mail: Cor.Verdouw@wur.nl

(Received xx June 2009; final version received xx Month Year)
Deleted: Configurators - A case in the

Dutch flower industry

Key challenge for mastering high uncertainty of both demand and supply is to attune products and business processes in the entire supply chain continuously to customer requirements. Product configurators have proven to be powerful tools for managing demand uncertainty. This paper assesses how configurators can be used for combined product and process configuration in order to support mastering high uncertainty of both supply and demand. It defines the dependence between product and process configuration in a typology of interdependencies. The addressed dependences go beyond the definition phase, and also include the effects of unforeseen backend events during configuration and execution. Based on a case study in the Dutch flower industry, a conceptual architecture is proposed for coordination of these interdependencies and development strategies are identified.

Keywords: configuration, supply chain management, mass customisation, concurrent engineering, ERP, flower industry

Deleted: z

Formatted: English (U.K.)

Deleted: A typical example is the flowers industry, especially due to the dependence on living materials.II

Deleted: ( 1993). The well-known bullwhip effect shows that amplification of demand uncertainty can be reduced by supply chain coordination (Lee et al., 1997). There are two main categories of supply chain uncertainties: i) inherent or high frequent uncertainties arising from mismatches of supply and demand, and ii) uncertainties arising from infrequent disruptions to normal activities such as natural disasters, strikes and economic disruptions (Van der Vorst and Beulens, 2002, Kleindorfer and

\footnotetext{
*Corresponding author. Email: Cor.Verdouw @wur.nl
} 
Saad, 2005, Oke and Gopalakrishnan, 2009). This paper is concerned with the first category of uncertainties, which can either be demand or supply related (Lee, 2002). For coping with the addressed uncertainties, Supply Chain Management (SCM) literature initially has focused on creating so-called lean supply chains that efficiently push products to the market. Lean supply chains build upon reduction of demand uncertainty, especially by product standardisation. Customers must choose from a fixed range of standard products that are made to forecast in high volumes. Business processes in lean supply chains can be highly automated by ERP systems (Davenport and Brooks, 2004).

In the late 1990s, the then dominant approach of leanness was criticised more and more. It was argued that in volatile markets it is impossible to remove uncertainty. Companies therefore should accept differentiation and unpredictability, and focus on better uncertainty management. Agility was proposed as an alternative approach that aims for rapid response to unpredictable demand in a timely and costeffective manner (Fisher, 1997, Christopher, 2000). It is founded on a mass customisation approach that combines the seemingly contradictory notions of flexible customisation with efficient standardisation (Davis, 1989, Pine et al., 1993, Chandra and Kamrani, 2004). This by fabricating parts of the product in volume as standard components, while achieving distinctiveness through customer-specific assembly of modules (Duray et al., 2000).

Besides product modularity and flexible assembly systems (c.f. Molina et al., 2005), product configurators are addressed as important enabling technologies (Duray et al., 2000, Zipkin, 2001, Forza and Salvador, 2002). Product configurators provide an interface for rapid and consistent translation of the customer's requirements into the product information needed for tendering and manufacturing (Sabin and Weigel, 1998, Forza and Salvador, 2002, Tseng and Chen, 2006, Reinhart et al., 2009).

Until then, SCM focused on strategies for coping with demand uncertainty. Lee (2002) was one of the first who stressed the impact of supply uncertainty on supply chain design. Supply chains characterised by high supply uncertainty require the flexibility to deal with unexpected changes in the business processes. Disturbances of logistics, production or supply of materials should rapidly be observed and lead to process changes including re-planning and re-scheduling, purchasing new material, hiring alternative service providers, or negotiating new customer requirements. The rigid planning and scheduling systems of traditional ERP systems may cause problems in this type of supply chain (Akkermans, et al., 2003, Zhao and Fan, 2007). Modular software approaches, in particular Service-Oriented Architecture (SOA), have been proposed to overcome these limitations. In these approaches, process models guide the workflow planning and execution in run-time information systems. This puts the emphasis on process configuration to achieve the required backend flexibility. Process configuration supports a rapid and consistent specification of the workflow that is needed to fulfil specific customer orders (Schierholt, 2001, and others). For example, local deliveries from stock follow a different workflow than exports that are produced to order. Moreover, it supports reconfiguration of the workflow in case of unexpected supply events, e.g. components that were originally planned to be produced can be re-planned to be purchased.

Supply chains characterised by both uncertain demand and supply require a combination of responsiveness to changing demand and the flexibility to deal with unexpected changes in the business processes. Following Lee (2002), we use the term agility to characterise these types of supply chains. In agile supply chains, demand requirements and supply capabilities, i.e. products and processes including resources,
Deleted: (Van der Vorst and Beulens, 2002, Kleindorfer and Saad, 2005, Oke and Gopalakrishnan, 2009)

Deleted: Present

Formatted: English (U.K.)

Deleted: z

Formatted: English (U.K.)

Deleted: (Davenport and Brooks, 2004)

Formatted: English (U.K.)

Deleted: $\mathrm{z}$

Formatted: English (U.K.)

Deleted: (Fisher, 1997, Christopher, 2000)

Formatted

Deleted: (Davis, 1989, Pine et al.,

1993, Chandra and Kamrani, 2004)

Formatted: English (U.K.)

Deleted:

Formatted ... [2]

Deleted: (Duray et al., 2000, Zipkin, 2001, Forza and Salvador, 2002)

Formatted

Deleted: (Sabin and Weigel, 1998,

Forza and Salvador, 2002, Stormer, 2009)

Formatted: English (U.K.)

Deleted: (...

Formatted: English (U.K.)

Deleted: $\mathrm{z}$

Formatted ... [4]

Deleted: (Akkermans et al., 2003, Zhao and Fan, 2007)

Formatted

Formatted: Indent: First line: $36 \mathrm{pt}$ Deleted: $\mathrm{z}$

Formatted: English (U.K.)

Deleted: (....

Formatted

Formatted

Formatted: English (U.K.)

Deleted:

Formatted 
should be continuously attuned. Therefore, both front-office and back-office systems need to be flexible and smoothly integrated. This paper explores the application of configurators to both products and processes to achieve this.

The majority of the existing configuration research focuses either on product or process configuration. However, interdependence among product and process configuration is relatively under-researched (c.f. Jiao et al., 2007, Chandra and Grabis, 2009). A literature review, which is presented hereafter, shows that available literature on this subject focuses on the definition domain, i.e. translation of customer requirements to an integrated design of products and manufacturing processes $\left(\mathrm{Jia}_{\mathrm{a}}\right.$ et al., 2000, De Lit et al., 2003, Jiao, et al.. 2005, Bley and Zenner, 2006). However, the presence of supply uncertainty results in a high mutual dependence also after the definition phase. During configuration and execution, the effects of unforeseen backend events on the defined product and fulfilment processes must continuously be evaluated based on the actual state of the required resources. No research is found that provides an integrated consideration of the interdependences during definition, configuration and execution, neither that develops the corresponding information architecture for coordination of this interdependence using configurators.

The present research aims to contribute to this gap by assessing how configuration software can be used for combined product and process configuration to support mastering high uncertainty of both supply and demand. More specific, it aims to i) identify the interdependences between product and process configuration, ii) design an information architecture for coordination of this interdependence using configurators, and iii) identify configurator development strategies. Focus is on the order fulfilment cycle that starts with configuring orders in interaction with customers and ends with delivering the finished goods (Lin and Shaw, 1998, Croxton, 2003),

In the remainder of this paper, we first give an account of the applied research method. Next, we introduce the problem context of the case study firm, which is a typical example of a company operating in agile supply chains. Subsequently, a literature overview is provided about the use of configurators for products and processes, and we define a typology of its interdependencies. The case-study results are then presented. The paper concludes by addressing challenges for future development and summarising the main findings.

\section{Research method}

The research used a design-oriented case study method to answer the research question addressed in the introduction. Design-oriented research aims to develop a body of generic knowledge that can be used in designing solutions to management problems (Van Aken, 2004). It is a foundational methodology in information systems research (Hevner et al., 2004). Design-oriented research is typically involved with 'how' questions, i.e. how to design a model or system that solves a certain problem. A case study strategy fits best for this type of questions, in particular in case of complex phenomena that cannot be studied outside its context (Benbasat et al., 1987, Yin, 2002). This characterises the present research, because it focuses on the interdependences between product configuration, process configuration and the planning and control of fulfilment. Therefore, we have chosen for an in-depth explorative case study research that puts the different related topic areas into context. In such a case study, it makes sense to focus on an extreme situation that clearly highlights the process of interest (Eisenhardt, 1989, Yin, 2002). In present research, this is the existence of supply uncertainty in addition to demand uncertainty. Therefore, we searched within a sector that is inherently involved with high supply 
uncertainty, i.e. the Dutch flower industry. Firms in this sector face high supply uncertainty because of the dependence on the growth of living materials. Production processes are, therefore, vulnerable to weather conditions, pests and other

uncontrollable factors. Next, we selected a firm within this sector that was characterised by high demand uncertainty. Additional criteria were product variety and practical reasons, in particular the firm's willingness to cooperate and the authors' familiarity in the domain.

Data collection is done in semi-structured open interviews with managers and employees of the case company, and additional desk research. In total, 14 persons have been interviewed in 9 interviews ( 5 managers and 9 employees). Division of roles:

- Management: Sales (1), Finance (1), Logistics (1), Production (1), CEO (1);

- Employees: Order Processing (1), Planning (2), Expedition (1), ICT (1), Production Seedlings (2), Production Cuttings (2).

The questionnaire comprises four main parts: supply chain structure, business processes, control and information management. Every section includes open questions both for mapping and evaluation (see appendix). Three in-depth interviews were held covering the complete questionnaire. The subsequent interviews focused on specific business processes and were combined with observation of the company's operations and systems.

The research was organised as follows. First we defined the dependence between product and process configuration in a typology of interdependencies based on

literature review. Second, the case-study firm was investigated in interviews and additional desk research. Next, the investigation results were matched with the developed theoretical framework to define the basic design requirements. The researchers then designed a conceptual information architecture for combined support of both product and process configuration. The designed architecture was tested in a Proof of Feasibility implementation at Sofon, a Dutch configurator vendor, and evaluated by the management of both the case-study firm and Sofon. Finally, general development strategies were abstracted from the case findings based of the developed theoretical framework.

\section{Configuration in the Dutch flower industry}

This section introduces the case firm and its need for product and process configuration.

\subsection{Dutch flower industry}

The Dutch flower industry is traditionally a strong and innovative sector with a leading international competitive position and a great impact on the national economy. It is internationally renowned as a strong cluster (Porter, 1998) that produces cut flowers and potted plants, mainly in greenhouses. Particularly production of potted plants has many similarities with manufacturing. It is also a form of discrete production, in which products are assembled from plants, flowerpots,

decorations, labels and packaging. Fabrication of potted plants also has some features of continuous production, because of the process of continuous growth, but potted plants remain discrete units, traceable at single product level.

The extent to what processes are order-driven differs a lot, not only among different companies but also within firms. For the spot market, products are made to stock and distribution is either to order (usually via traders) or anticipatory (usually 
via auctions). For other cases, plants are often produced to forecast, while assembling, labelling and packaging are order-driven.

| The flower industry is characterised by high uncertainty of both demand and supply. Supply uncertainty is high, because chains are vulnerable to product decay, weather conditions, pests, traffic congestion and other uncontrollable factors. Further, also demand uncertainty is high amongst others because of weather-dependent sales, changing consumer behaviour, and increasing global competition. This results in high variability of supply capabilities and demand requirements in terms of volume, time, service levels, quality and other product characteristics.

\subsection{Case company profile}

The case company is a global supplier of a wide range of young potted plants. It is a rapidly growing company, with 350 staff and with production locations in Holland, Brazil, Kenya, Israel and Zimbabwe. Annually, over 100 million young plants are delivered as input material to growers or wholesalers.

The firm is characterised by high product variety. It produces about 800 varieties in six main categories, including Begonia and Cyclamen. Besides, over 400 varieties are sourced from other producers to offer a complete assortment. Varieties differ, among others, in colour, shape, and growing characteristics. The firm propagates young plants in two basic ways: as seedlings or cuttings. Seedlings can be sold at different stages of the growing process. Cuttings can be sold rooted or unrooted; and in different sizes. All young plants can be delivered in different types of trays. Furthermore, delivery conditions vary. For example: due to product-inherent characteristics, some varieties can only be delivered in specific periods, and quality and prices are often time-dependent. Furthermore, royalties differ per variety and per continent.

Also process variety is high. Production differs between seedlings and cuttings. For seedlings, seeds are sourced from breeders, seeded in trays and budded. Budded seeds can be sold directly or grown further. Seedlings are mostly seeded to customer order, but also produced to forecast or sourced to order (especially for specific variety mixtures). Cuttings are mostly produced by the firm, but are also sourced from third parties. Production of cuttings starts with propagation and growing of parent plants, which is done in southern countries for reasons of climate and labour costs. After almost two years, cuttings can be harvested. They are shipped directly to customers, or transported to Holland for rooting. Unrooted cuttings can be stored for 10 days at the most, including 3 days for transportation. The company strives for order-driven harvesting and rooting of cuttings, but production to stock also occurs. Furthermore, logistics are complex, due to the global distribution of both production locations and customers, combined with high requirements concerning delivery leadtimes and flexibility.

\subsection{Need for combined product and process configuration}

The interviews indicated that the case company is characterised by high uncertainty of both demand and supply. Demand requirements (about product features, quality and service levels) are diverse and difficult to predict. Also predictability of the demand amount and time is low, although basic seasonable patterns can be determined. Moreover, the lead-times, yields and qualities of production very much depend on the growth of living materials.

The company deals with this high uncertainty by providing variety in their product assortment and flexibility in meeting customer demands with respect to 
product specifications and delivery schedules. To date, it has relied heavily on improvisation by experienced employees. However, since the company is growing, they face problems in keeping this manageable, which set limits to further growth. As a consequence, the interviewees in particular stressed the lack of tools for customer requirement definition based on real-time information of the supply capabilities, as well as flexible back-office systems for (re)planning, (re)scheduling and monitoring of order fulfilment. The addressed most urgent bottlenecks are:

- Knowledge of production processes and options to reconfigure these processes is only implicitly available in the minds of some experienced staff members. This problem is manageable with the firm's current scale, but inhibits further growth.

- Information systems are fragmented and poorly integrated. They require a lot of manual data re-entry. Information inconsistency leads to larger safety buffers than strictly required, and many redundant data checks and duplicate registrations are performed.

- Mid-term planning is not coordinated with operational data, due to a lack of system integration.

The company's management assessed existing ERP systems for solving these problems, but evaluated them to lack the required flexibility. Therefore, the firm decided to consider implementation of configuration software for products and processes, in combination with an ERP system, as possible option to master uncertainty.

\section{Role of configurators in supply chain management}

This section provides some conceptual background about the use of configurators and defines the dependence between product and process configuration in a typology of interdependencies.

\subsection{Product configurators in responsive supply chains}

Configurators have emerged from the development of rule-based product design in the field of Artificial Intelligence. A well-known early application was R1, a product configurator for VAX computers (McDermott, 1981). A product configurator is a tool that guides users interactively through specification of customer-specific products (Sabin and Weigel, 1998, Forza and Salvador, 2002, Tseng and Chen, 2006, Reinhart et al., 2009), Configurators generate specific product variants by combining sets of predefined components and specifying features according to permitted values. Next,

Formatted: Font: Italic

Deleted: (Sabin and Weigel, 1998, Forza and Salvador, 2002, Stormer, 2009) they check the completeness and consistency of configured products based on rules that define the interdependencies between components or features. Product configurators are based on generic product models, which define the class of objects that can be configured (Hegge and Wortmann, 1991).

Currently, configurators play an important role in responsive supply chains, which are characterised by high demand uncertainty and low supply uncertainty (Lee, 2002). They are widely used for product configuration to enable rapid response to customer demands. In interaction with the user, the software generates consistent and complete specifications of customised products, taking into account both customer's requirements (e.g. functional specifications and delivery conditions) and feasibility of production, sourcing and delivery. Along with the product specification, current configurators can produce commercial offers and draft contracts, and schedules and contracts for support and maintenance of the product. The software can be designed

for use either by a sales representative of the supplier, or by a customer, e.g. through the internet. In both cases the configuration process results in a quick and effective
Deleted: e.g.

Deleted: e.g. 
order specification that can directly be entered into the production planning and scheduling systems.

\subsection{Configuration in agile supply chains}

Next to demand uncertainty, agile supply chains are also characterised by high uncertainties at the supply-side (Lee, 2002). High supply uncertainty makes great demands on the flexibility of supporting information systems. The development of modular software approaches especially has been advocated for realizing this flexibility (for example Verwijmeren, 2004). Service-Oriented Architecture (SOA) is the latest development in software modularity (Wolfert et al., 2010). In a SOA approach, business process models are leading in routing event data amongst multiple I application components that are packaged as autonomous, platform-independent | services (Erl, 2005, Papazoglou et al., 2007), Consequently, new or adapted business I processes can be supported without changing the underlying software. Induced by the emergence of Service-Oriented Architecture, also ERP vendors have commenced to

modularise their software (Møller, 2005, Loh et al., 2006).

The leading role of business processes in modular software approaches puts emphasis on rapid configuration of processes in achieving flexibility. The concept of process configuration is introduced by Schierholt (2001), who applied the principles of product configuration to support process planning. Rupprecht et al. Zhou and Chen (2008) described approaches for automatic configuration of business process models for specific projects Jiao et al. (2004) formalised the modelling of process configurations for given product configurations. Verdouw et al. (2010) argue that reference process models should be set-up as dynamic configurable models to enable ICT mass customisation and they assess the readiness of existing models. Furthermore, the ERP vendor SAP has addressed process configuration to manage the complexity of their reference process models that are used as a basis for system implementation. They conducted extensive research to make these models configurable (Dreiling et al., 2006, Rosemann and van der Aalst, 2007). Building upon this, Rosa et al. (2007) proposed a questionnaire-driven approach to guide users interactively through process model configuration.

Nevertheless, the majority of existing literature focuses either on product or on process configuration. The mutual dependence between product and process configuration is relatively under-researched (c.f. Jiao et al., 2007, Chandra and Grabis, 2009). The papers, found in our literature review, all focus on the definition domain, i.e. translation of customer requirements to an integrated design of products and manufacturing processes. Jiao et al. (2000) put forward an integrated product and process model that unifies Bill-of-Materials and routings, called generic Bill-ofMaterials-and-Operations. Jiao et al. (2005) proposed a product-process variety grid to unify product data and routing information. De Lit et al. (2003) introduced an integrated approach for product family and assembly system design. (2006) developed an approach to integrate product design and assembly planning.

As argued before, the presence of supply uncertainty results in a high mutual dependence also after the definition phase. During configuration and execution, the effects of unforeseen backend events on the defined product and fulfilment processes must continuously be evaluated based on the actual state of the required resources.

However, no research is found that explicitly considers the interdependences during definition, configuration and execution, and that develops the corresponding

information architecture for coordination of this interdependence using configurators.

\begin{tabular}{|c|}
\hline Deleted: z \\
\hline Deleted: ( \\
\hline Deleted: \\
\hline Formatted: Font: Italic \\
\hline Formatted: Font: Italic \\
\hline $\begin{array}{l}\text { Deleted: (Erl, 2005, Papazoglou et al., } \\
\text { 2007) }\end{array}$ \\
\hline Deleted: z \\
\hline Formatted: Font: Italic \\
\hline Deleted: (Møller, 2005) \\
\hline Formatted: English (U.K.) \\
\hline Deleted: ( \\
\hline Deleted: \\
\hline Deleted: ( \\
\hline Deleted: , \\
\hline Deleted: has \\
\hline Deleted: an \\
\hline Deleted: in virtual enterprises \\
\hline Deleted: ( \\
\hline Deleted: \\
\hline Deleted: $\mathrm{z}$ \\
\hline Deleted: in order \\
\hline Formatted: Font: Italic \\
\hline $\begin{array}{l}\text { Deleted: (Dreiling et al., 2005, } \\
\text { Rosemann and van der Aalst, 2007) }\end{array}$ \\
\hline Deleted: \\
\hline Deleted: ( \\
\hline Deleted: \\
\hline Formatted: English (U.K.) \\
\hline Formatted: Font: Italic \\
\hline Formatted: Font: Italic \\
\hline $\begin{array}{l}\text { Deleted: (Jiao et al., 2007, Chandra and } \\
\text { Grabis, 2009) }\end{array}$ \\
\hline Deleted: i.e. \\
\hline Formatted: English (U.K.) \\
\hline Deleted: ( \\
\hline Deleted: , \\
\hline Deleted: ( \\
\hline Deleted: , \\
\hline Deleted: ( \\
\hline Deleted: \\
\hline Deleted: (Bley and Zenner, 2006) \\
\hline Formatted: English (U.K.) \\
\hline Deleted: 1 \\
\hline
\end{tabular}


Therefore, in next section we first develop a typology of product and process

interdependences based on organisational literature.

\subsection{Typology of interdependences between product and process configuration}

Dependence is a central notion of the General Systems Theory. This theory argues that the whole of a system is more than its parts, because of the existence of dependencies between their elements (Bertalanffy, 1950). Thompson (1967) was one of the first to apply this idea to organisational theory. He distinguished three basic types of dependency: pooled, sequential and reciprocal interdependence, which require different coordination modes: coordination by standardisation, by plan and by mutual adjustment. His work is refined by many others, all focusing on coordination of generic dependencies between organisational subunits. Malone and Crowston (1994) have introduced different types of dependencies between activities and resources. They distinguish between flow, sharing and fit dependencies (see also | Malone et al., 1999). Flow dependencies arise whenever one activity produces a resource that is used by another activity (precedence relation). Sharing dependencies occur whenever multiple activities all use the same resource. Fit dependencies arise when multiple activities collectively produce a single resource.

If we apply these interdependencies to product and process configuration, distinction should be made between different decision levels, i.e. definition, configuration and execution. First, in the definition phase designers predefine reference product and process models. These are generic models, or family models, which define the possible product and process components, and that include rules that define the possible combinations of components. A product reference model is constrained by the available business processes as defined in process reference models. Vice versa, a process reference model must contain the business processes that produce the variety of products as defined in product reference models. Second, the configuration phase starts when a customer order request comes in. A customised product is configured in interaction with the customer, and taking into account whether the enabling business process can be configured. Therefore, the required input products and capacity must be available to promise. The result is an accepted order, which triggers configuration of the business processes that fulfil the order. These might include distribution activities (Make to Stock), and production activities (Assemble / Make to Order), and engineering activities (Engineering to Order). Last, the execution phase comprises planning, scheduling and completion of the configured business processes. The progress is monitored continuously and if necessary the product and process configurations are updated.

Figure 1 more precisely defines the interdependence among product and process configuration in a typology of dependencies. This typology is an application of the categorisation of Malone and Crowston (1994) and Malone et al. (1999) as discussed above.

$<$ insert figure $1>$

Product configurators are primarily means for coordination of fit dependencies: assembling consistent product variants that meet specific customer requirements from available components and options. Analogously, process configuration coordinates the assembly of consistent process variants from available activities or services. The alignment of product and process configuration requires coordination of precedence (flow) dependencies: process configuration is conditional for product configuration and vice versa. Furthermore, process configuration depends on operational execution
Deleted: $\mathrm{z}$

\begin{tabular}{|l|}
\hline Deleted: ' \\
\hline Deleted: ( \\
\hline Deleted: , \\
\hline Formatted: English (U.K.) \\
\hline Formatted: English (U.K.) \\
Deleted: z \\
Formatted: English (U.K.) \\
Deleted: (Malone and Crowston, 1994) \\
\hline Deleted: (
\end{tabular}

Deleted: i.e.

Deleted: ly

Deleted: $\mathrm{z}$

Formatted: English (U.K.)

Deleted: $z$

Formatted: Font: Italic

Deleted: (Malone and Crowston, 1994,

Malone et al., 1999) 
because fulfilment of the configured process needs capacity and input products. More specific, the defined interdependencies are:

(1) Product Assembling: multiple product modules are required to produce a single product (fit dependency). Product configurators are primarily means for coordination of this dependency. They specify components, options, interfaces and interdependency rules in reference product models and guide customerspecific configuration of product variants.

(2) Process Rules Precedence: process properties set constraints to possible product configurations. Consequently, process reference models are a precondition for product reference models (flow dependency). This dependency is mostly coordinated by mutual adjustment of product and process models by designers, ideally supported by tools that ensure consistency of both model types.

(3) Order Precedence: specific product configurations (order information) are input for configuration of specific fulfilment processes (flow dependency). Therefore, order information must be interpretable by back-office systems for production and distribution. This dependency can be coordinated by standardisation of order data in an executable form, including Bill-of-Materials.

(4) Process Assembling: multiple activities, j.e. process modules, are required to compose a single process (fit dependency). Process configuration is primarily a mechanism to coordinate this dependency. It specifies the activities, interfaces and interdependency rules in reference process models and guides configuration of order-specific processes.

(5) Process Precedence: the output of the process configuration task is conditional for the planning and scheduling of the fulfilment (flow dependency). Execution of a configured process consumes input products (raw material or semi-finished products) and uses capacity. This dependency can be coordinated by standardisation of configured processes in a model format that is interpretable by planning and scheduling systems.

(6) Product Precedence: for execution of a fulfilment process, the required input products must be available (flow dependency). This dependency can be coordinated by integration with planning and scheduling mechanisms.

(7) Capacity Precedence: for order-driven processes, the required capacity must be available (flow dependency). This can be coordinated by integration with planning and scheduling mechanisms.

(8) Capacity Rules Precedence: the characteristics of used capacity (e.g. machine setup, other facility layouts, and human resource competences) set constraints for the possibilities for process configuration (flow dependency). This can be coordinated similarly to Process Rules Dependencies: mutual adjustment of capacity layouts and process models by designers ideally supported by tools that ensure model consistency.

The last dependencies to be mentioned are related to operational execution of configured processes:

(9) Product Consumption: multiple configured processes all use the same input products (sharing dependency).

(10) Capacity Usage: configured processes for multiple orders all use the same capacity (sharing dependency).

(11) Capacity Assembling: multiple capacity units are required to set up specific layouts (fit dependency). 
These last three dependencies are coordinated by planning and scheduling systems. They do not directly impact product and process configuration (only via product, capacity and process precedence's) and are thus beyond the scope of this paper.

\section{Information architecture for combined product and process configuration}

This section describes a conceptual information architecture for combined support of both product and process configuration, including a Proof of Feasibility implementation in a configurator.

\subsection{Basic design requirements}

The uncertainty of both demand and supply of the case company is high, as section 2 demonstrates. Demand requirements (about product features, quality and service levels) are diverse and difficult to predict. Also predictability of the amount and time is low, although basic seasonable patterns can be determined. Moreover, the leadtimes, yields and qualities of production very much depend on uncontrollable factors.

In order to make this variability manageable, the solution to be designed must support coordination of the high interdependence between the company's products and processes during:

- Definition: it must be possible to define integrated reference models, which cover the variety of the firm's products and enabling processes, and that take into account the constraints arising from its specific process characteristics;

- Configuration: it must be possible to configure customised products and the accompanying processes, in interaction with the customer and taking into account whether the required input products and capacity are available to promise;

- Execution: it must be possible to implement the configured business processes in the company's backend systems, to monitor its progress and update product and process configurations if necessary.

More specifically, these basis requirements imply that the design must support coordination of the dependences as developed in previous section. Table 1 identified these dependencies for the case company by matching the investigation results with the defined typology. The remainder of this section develops a corresponding information architecture, including a Proof of Feasibility implementation in the configurator Sofon.

\subsection{Information architecture for product configuration}

Sofon Guided Selling is a model-based product configurator. It provides functionality for the definition of questionnaires that guide users interactively through requirements specification and translate this information to product configurations in the form of Bills-of-Materials, quotation calculations, visualisations and document generation. Most users utilise Sofon as a front-office system, in combination with an ERP system for the back-office. Figure 2 illustrates the underlying information architecture. $<$ insert figure $2>$

The focus is on coordination of Product Assembling dependencies. Therefore, functionality is provided to specify the product range, possible features, and rules that define permitted selections in reference product models. Additionally, other order specifications such as delivery dates can be defined here. Product experts can enter configuration rules into the configurator's repository. Product data (Bill-of-Materials, part numbers, prices) and process data (routing, lead times, production cost) can be 
copied from ERP master data, to ensure that production orders will be in terms that can be interpreted by ERP systems (Process and Capacity Rules Precedence).

Questionnaires are then generated that guide configuration, either directly by the customer or through a sales representative. The configured product and other customer specifications (orders, Bill of Material) are generated in a format that can be executed by ERP systems (Order Precedence). Also, basic order-specific routings can be generated that serve as a basis for planning and scheduling (Process Precedence).

For the case firm, the reference product model includes product categories (including Begonia and Cyclamen), specific varieties and product features, such as budded seeds or grown up, cutting size, rooted or unrooted, possible tray types, delivery conditions and royalty types. Figure 3 presents a simplified example in Sofon. $<$ insert figure $3>$

The figure shows that the generic model is defined in two ways. The main part is the definition of wizard-like questionnaires in the language of customers. The generic questionnaire is defined to the left of the screen and possible answers are shown to the top-right of the screen. At the bottom, the product model is specified as a generic Billof-Materials (BOM) that is executable by ERP systems. During configuration, selections made in the questions are specified automatically into this BOM. For example: based on the selection of the colour red, the variety 'Begonia Elatior Baladin' is defined (see figure 3: article code BE72).

\subsection{Information architecture for combined product and process configuration}

Currently, configurators such as Sofon focus on product configuration in the responsive segment. Agile supply chains require combined product and process configuration. Two essential differences can be distinguished: i) introduction of process configuration between product configurators and planning and scheduling systems, and ii) dynamic alignment of resulting interdependencies. In the case study, Sofon was used to develop an information architecture for this and to evaluate the feasibility of configurators. Figure 4 shows the resulting conceptual model.

$<$ insert figure 4>

Analogous to product configuration, the focus of process configuration is on the coordination of Process Assembling dependencies, i.e. to assemble specific order fulfilment processes from multiple activities (process modules). Therefore, standard process models can be specified and the composition of customer-specific processes can be guided by configurator tools. However, the important difference with product configuration is that most information required for process configuration is available in the system. Two important information sources can be distinguished for process configuration: customer orders (output of product configuration) and availability of required input products and capacity (output of ERP back-office system). Neither of these types of information needs to be specified manually during process configuration.

Although Sofon focuses on companies in the responsive segment that do not face high supply uncertainties, the tool can be applied to configure processes in the same way that it is used to configure products. Figure 5 presents an example for the case company using Sofon's existing functionality.

$<$ insert figure $5>$

It shows that there are three additional questions for the configuration of the young plant order fulfilment processes, all of which are answered automatically. The questions concerning capacity and product availability are queries to ERP back-office 
systems. The question "How far order-driven?" is answered by an automatic calculation using the retrieved data about product and capacity availability and information about the required versus possible lead-time. The required delivery leadtime is as specified during product configuration. The possible lead-time is the sum of all order-driven fulfilment processes. The calculation result is input for activity specification in the generic routing (i.e. Bill of Activities) that is executable by ERP systems (see right-bottom at figure 5).

Consider, for example, an illustrative order for Cyclamen. The customer specification, resulting from product configuration, shows that this is an order for 2000 budded 'Cyclamen Miniwella Twinkle blanc' to be delivered within 4 days in 66-66-44 trays to Hamburg, Germany. Operational ERP data shows that these are in stock and that distribution will take two days. Thus, only distribution activities are on customer order and these activities are selected for this order (see figure 5: D2.5 and further).

Consider another simplified example: an order for Begonia cuttings. The configured order shows that this is an order for 5000 rooted 'Begonia Eliator Baladin' to be delivered in 7 weeks in 72-72-44 trays to Latina, Italy. Operational ERP data shows that the required cuttings are available at parent plants in Brazil and that the required air freight and greenhouse capacity is also available. The lead-time of rooting cuttings from these parent plants is 5 weeks. The total lead-time from harvesting until delivery at the customer site is 6 weeks and 3 days. This is less than 7 weeks, so all activities from harvesting onwards can be on customer order. Consequently, all activities for production of cuttings and for distribution are selected in the generic routing (see right-bottom at figure 5).

\subsection{Configurator development strategies}

The previous analysis shows that product configurators also can be used to support process configuration. Below, it is evaluated more precisely to what extent the identified basic requirements can be met by existing configurators. This by discussing how coordination of the defined interdependencies is supported (see figure 1):

(1) Product Assembling: is well supported, since this is the traditional focus of configurators. For example: Sofon provides rich functionality for defining generic product models in wizard-like questionnaires and accompanying rules, and generic Bill-of-Materials.

(2) Process Rules Precedence: requires solid integrations with back-office systems and mechanisms to prevent redundant process logic or to ensure consistency. For example: Sofon provides functionality to copy master data from ERP, CAD, and PDM packages, but alignment has to be done manually by product experts; consistency checks are not supported.

(3) Order Precedence: configurators and ERP systems must be technically integrated and order-related data must be defined in a format that is executable by backoffice systems. Especially in agile supply chains, functionality is required for reconfiguration of order-related data if changes in the back-office occur. For example, Sofon contains rich functionality for defining standard orders and accompanying Bill-of-Materials and it provides standard application connectors for ERP packages. However, reconfiguration of adjusted requirements after contract conclusion is not supported.

(4) Process Assembling: this could be supported by applying available product configuration functionality to processes. However, adequate process configuration requires rich functionality to specify reference process models and to configure 
Business Process Models based on configured orders and operational back-office data. In existing questionnaire-based product configurators, this functionality might be rather basic. For example, in Sofon, generic routings for customerspecific processes can be configured, but this functionality just lists activities, possibly including fixed lead-times. It does not specify possible interactions and sequences among activities, and it is not possible to derive activity lead-times from operational data.

(5) Process Precedence: configured processes should be executable in back-office systems to orchestrate order-specific fulfilment, including product reconfigurations. For compatibility with different software environments, process models should be configured in XML-standard notations (i.e. BPMN and BPEL) that are executable in any SOA-compliant back-office system or integration platform. For example, in Sofon order-specific routings can be configured and executed by planning and scheduling systems. However, as argued at the previous dependency, this is rather basic decomposition information. Sofon does not yet support the configuration of BPMN and BPEL process models.

(6) Product Precedence: in product configurators, product availability data can be incorporated into configuration, e.g. to determine the Availability to Promise (ATP). This functionality could also be used for process configuration. For example, in Sofon it is possible to define questions that retrieve data automatically from back-office systems.

(7) Capacity Precedence: particularly in the case of order-driven production, capacity availability data is also needed. This can be retrieved in the same way as product availability data.

(8) Capacity Rules Precedence: in this case, required functionality is similar to Process Rules Precedence: solid integration with back-office and mechanisms to prevent redundant capacity logic or to ensure consistency.

(9) Product Consumption, (10) Capacity Usage and (11) Capacity Assembling: these dependencies are supported by back-office systems for planning and scheduling and are beyond the scope of configurators.

All together, it is found that product configurators do not yet provide sufficient functionality for combined product and process configuration. Especially, intensive interaction among product configuration, process configuration and execution in back-office systems is poorly supported. Based on the analysis, three basic configurator development strategies are distinguished. The strategies involve different implementations of the developed information architecture (see figure 4) in particular different divisions of product configuration, process configuration and management of the order fulfilment among dedicated configurator software and the ERP system.

First, existing product configurators can be made appropriate for reconfiguration and intensive interaction with back-office systems At this option, functionality for product and process configuration is provided by different applications. Process configuration is done outside product configurators, either within ERP systems or in service-oriented middleware. In addition to existing functionality, the product configurator includes functionality for synchronisation of order-related data (Order Precedence) and process logic (Process Rules Precedence).

The second alternative is to extend configurators with functionality for process configuration and for coordination of the different interdependences that haven defined. For this option, both product and process configuration are incorporated within one configurator and this tool is integrated with external planning \& scheduling systems, either directly or via service-oriented middleware. The external

Deleted:

Deleted: other

Deleted: , while leaving process configuration to back-office systems either through inclusion in ERP software, or in service-oriented middleware.

Deleted: z

Deleted: II

Deleted: add

Deleted: 
integration focuses on exchange of process flows (Process Precedence), product \& capacity data (Product \& Capacity Precedence), and capacity layouts (Capacity Rules Precedence).

Last option is to include both product and process configuration into the ERP system and thus integrate all features (product configuration, process configuration and planning and scheduling) within one system. In this case, the ERP system is also the front office for customer interaction. All identified dependencies are supported by integrations within the system.

|

\section{Summary and Outlook}

The objective of this paper was to asses how configuration software can be used for combined product and process configuration to support mastering high uncertainty of both supply and demand. In order to answer this question, first the role of configurators in Supply Chain Management has been discussed. The traditional domain of configurators is in responsive supply chains, i.e. high demand uncertainty with reliable and stable supply. The additional presence of supply uncertainty in agile supply chains results in a high mutual dependence between product and processes, not only in the definition phase, but also during configuration and execution. First, in the definition phase, designers predefine integrated reference product and process models. A product reference model is constrained by the available business processes as defined in process reference models. Vice versa, a process reference model must contain the business processes that produce the variety of products as defined in

product reference models. Second, in the configuration phase customised products are configured in interaction with the customer and taking into account whether the

enabling business processes can be configured. Therefore, the required input products and capacity must be available to promise. The result is an accepted order, which

triggers configuration of the business processes that fulfil the order. Last, the execution phase comprises planning, scheduling and completion of the configured

business processes. The progress is monitored continuously and if necessary the product and process configurations are updated. The interdependence of products and processes during definition, configuration and execution has been defined more precisely in a typology of interdependencies.

In order to support coordination of the defined interdependencies, configurators must provide additional functionality for process configuration that links product configurators and planning and scheduling systems. Based on a case study in the Dutch flower industry, a conceptual information architecture has been proposed for this and tested in a Proof of Feasibility implementation. It has been found that currently flexible process configuration and back-office/frontoffice/customer communication are not sufficiently supported. Based on the developed information architecture, three basic development strategies have been identified, each including a different division of product configuration, process configuration and management of the order fulfilment among dedicated configurator software, ERP systems and service-oriented middleware. On the other hand, the case study has shown that the investigated firm heavily relied on improvisation by experienced staff having in-depth product and process knowledge. This type of tacit knowledge is to be captured in the system for successful application of combined product and process configuration.

The main contribution of this paper to existing literature is that it provides an integrated typology of product and process interdependences and it develops a

\begin{tabular}{|c|}
\hline Deleted: software \\
\hline Deleted: i.e. \\
\hline Formatted: English (U.K.) \\
\hline $\begin{array}{l}\text { Deleted: These are generic models, or } \\
\text { family models, which define the possible } \\
\text { product and process components, and } \\
\text { include rules that define the possible } \\
\text { combinations of components. }\end{array}$ \\
\hline Deleted: \\
\hline Deleted: ly \\
\hline $\begin{array}{l}\text { Deleted: starts when a customer order } \\
\text { request comes in. A }\end{array}$ \\
\hline Deleted: $\mathrm{z}$ \\
\hline Deleted: is \\
\hline Deleted: \\
\hline Formatted: English (U.K.) \\
\hline $\begin{array}{l}\text { Deleted: } \mathbb{I} \\
\text { Th }\end{array}$ \\
\hline $\begin{array}{l}\text { Deleted: for configurators that add } \\
\text { value for firms in the agile segment }\end{array}$ \\
\hline Deleted: \\
\hline $\begin{array}{l}\text { Deleted: The first option is to make } \\
\text { product configuration functionality } \\
\text { appropriate for reconfiguration and } \\
\text { intensive interaction with back-office } \\
\text { systems. At this, process configuration is } \\
\text { done outside product configurators, either } \\
\text { within ERP systems or in service-oriented } \\
\text { middleware. The second strategy is to add } \\
\text { functionality for process configuration. } \\
\text { For this option, product and process } \\
\text { configuration are incorporated within one } \\
\text { configurator and this tool is integrated } \\
\text { with external planning \& scheduling } \\
\text { systems, either directly or via service- } \\
\text { oriented middleware. Last alternative is } \\
\text { to include product and process } \\
\text { configuration into the ERP system and } \\
\text { thus integrate all features within one } \\
\text { system. I }\end{array}$ \\
\hline Formatted: English (U.K.) \\
\hline Formatted: English (U.K.) \\
\hline
\end{tabular}


corresponding information architecture for its coordination. Contrary to related work, the addressed dependences go beyond the definition phase and do also include the effects of unforeseen backend events during configuration and execution. As a result, the developed architecture supports the mastering of both demand and supply uncertainty, which exceeds the traditional application domain of configurators.

The research encompasses an explorative analysis that is based on a single case study. Advantage of this approach is that it puts the different related topic areas of the studied complex phenomena into context. This is in line with Jiao et al. (2007) who stresses the need for a holistic view and system-wide solutions. However, an important weakness of single case study research in general is the little basis for scientific generalisation. In the paper we used the typology of dependencies based on literature as core vehicle to abstract general development strategies from the case study. Nevertheless, future research is needed to further develop, test and implement the designed architecture. Important remaining issues include: i) development of configurable reference process models that bridge between product configuration and back-office systems, ii) broad feasibility survey of existing configurators, iii) implementation of the designed architecture in combination with ERP and SOA platforms, and iv) case studies that test the applicability in other sectors.

\section{Appendix - Questionnaire}

Structure of the questionnaire and main questions:

A. Introduction

- Please, could you introduce your organisation and your current function?

- What are the main products of your organisation?

B. Supply Chain Structure

- Which are the main organisations in your Supply Chain?

Formatted: English (U.K.)

Deleted: (

Deleted:

Formatted: English (U.K.)

Formatted: English (U.K.)

Deleted: z

Formatted: English (U.K.)

- To what extent do your customers demand your company specific requirements?

- How far do you collaborative with your customers? (including type of arrangements).

- How do you evaluate the current cooperation, j.e. what are the most important success factors and points for improvement?

C. Business Processes

- Please, could you describe the business processes in which you are involved?

- How far are your business processes integrated in the supply chain?

- What are the most important bottlenecks in current business processes?

D. Control

- To what extent are your processes order-driven?

- How do you make your future (production) planning?

- What are your most important control challenges?

E. Information Management

- What are your main information systems?

- How far are you satisfied with your information systems?

- What is your vision about the possibilities of ICT for better performance?

To conclude

- How does your organisation look like 5 years hence?

\section{Deleted: $\mathrm{z}$}

Deleted: $\mathrm{z}$

Deleted: $\mathrm{z}$
Deleted: i.e.

Formatted: Numbered lists, Line spacing: single

Formatted: Bullets and Numbering 


\section{References}

Akkermans, H.A., Bogerd, P., Yucesan, E. and Van Wassenhove, L.N., 2003. The impact of ERP on supply chain management: Exploratory findings from a European Delphi study. European Journal of Operational Research, 146 (2), 284.

Benbasat, I., Goldstein, D.K. and Mead, M., 1987. The Case Research Stratey in Studies of Information Systems. MIS Quarterly, 11 (3), 369-385.

Bertalanffy, L.V., 1950. An Outline of General System Theory. The British Journal for the Philosophy of Science, 1 (2), 134-165.

Bley, H. and Zenner, C., 2006. Variant-oriented Assembly Planning. CIRP Annals - Manufacturing Technology, $55(1), 23-28$.

Chandra, C. and Grabis, J., 2009. Role of flexibility in supply chain design and modeling--Introduction to the special issue. Omega, 37 (4), 743-745.

Chandra, C. and Kamrani, A.K., 2004. Mass Customization: A Supply Chain Approach. New York: Kluwer Academic / Plenum Publishers.

Christopher, M., 2000. The Agile Supply Chain: Competing in Volatile Markets. Industrial Marketing Management, 29 (1), 37-44.

Croxton, K.L., 2003. The Order Fulfillment Process. The International Journal of Logistics Management 14 (1), 19-32.

Davenport, T.H. and Brooks, J.D., 2004. Enterprise systems and the supply chain. Journal of Enterprise Information Management, 17 (1), 8-19.

Davis, S., 1989. From future perfect: Mass customizing. Planning Review, 17 (2), 16-21.

Davis, T., 1993. Effective Supply Chain Management. Sloan Management Review, 34 (4), 35-46

De Lit, P., Delchambre, A. and Henrioud, J.-M., 2003. An integrated approach for product family and assembly system design. IEEE Transactions on Robotics and Automation, 19 (2), 324- 334.

Dreiling, A., Rosemann, M., Van Der Aalst, W. '. Heuser, L. and Schulz, K., $20 \overline{0} \overline{6}$. Model-based software configuration: patterns and languages. European Journal of Information Systems, 15 (6), 583-600.

Duray, R., Ward, P.T., Milligan, G.W. and Berry, W.L., 2000. Approaches to mass customization: configurations and empirical validation. Journal of Operations Management, 18 (6), 605-625.

Eisenhardt, K.M., 1989. Building Theories from Case-Study Research. Academy of Management Review, 14 (4), 532-550

Erl, T., 2005. Service-Oriented Architecture: Concepts, Technology, and Design Englewood Cliffs: Prentice Hăli PTR.

Fisher, M.L., 1997. What is the right supply chain for your product? Harvard Business Review, 75 (2), 105-116.

Forza, C. and Salvador, F., 2002. Product configuration and inter-firm co-ordination: an innovative solution from a small manufacturing enterprise. Computers in Industry, 49 (1), 37-46.

Hegge, H.M.H. and Wortmann, J.C., 1991. Generic bill-of-material: a new product model. International Journal of Production Economics, 23 (1-3), 117-128.

Hevner, A.R., March, S.T., Park, J. and Ram, S., 2004. Design science in Information Systems research. Mis Quarterly, 28 (1), 75-105.

Jiao, J., Simpson, T.W. and Siddique, Z., 2007. Product family design and platform-based product development: a state-of-the-art review. Journal of Intelligent Manufacturing, 18 (1), 5-29.

Jiao, J., Tseng, M.M., Qinhai, M. and Yi, Z., 2000. Generic Bill-of-Materials-and-Operations for HighVariety Production Management. Concurrent Engineering, 8 (4), 297-321.

Jiao, J., Zhang, L. and Pokharel, S., 2005. Coordinating product and process variety for mass customized order fulfilment. Production Planning \& Control, 16 (6), 608 - 620.

Jiao, J., Zhang, L. and Prasanna, K., 2004. Process Variety Modeling for Process Configuration in Mass Customization: An Approach Based on Object-Oriented Petri Nets with Changeable Structures. International Journal of Flexible Manufacturing Systems, 16 (4), 335-361.

Kleindorfer, P.R. and Saàd, G.'.'., 2005. Managing Disruption Risks in Supply Chains. Production and Operations Management, 14 (1), 53-68.

Lee, H.L., 2002. Aligning supply chain strategies with product uncertainties. California Management Review, 44 (3), 105-119.

Lee, H.L., Padmanabhan, V. and Whang, S.J., 1997. Information distortion in a supply chain: The bullwhip effect. Management Science, 43 (4), 546-558.

Lin, F.R. and Shaw, M.J., 1998. Reengineering the order fulfillment process in supply chain networks. International Journal of Flexible Manufacturing Systems, 10 (3), 197-229.

Loh, T.C., Koh, S.C.L. and Simpson, M., 2006 . An investigation of the value of becoming an extended enterprise. International Journal of Computer Integrated Manufacturing, 19 (1), 49-58.

Formatted $\ldots[10]$

\begin{tabular}{|lr|}
\hline Formatted & $\ldots[11]$ \\
\hline Formatted & $\ldots[12]$ \\
\hline Formatted & $\ldots[13]$ \\
\hline
\end{tabular}

\begin{tabular}{|lr|}
\hline Formatted & $\ldots[14]$ \\
\hline Formatted & $\ldots[15]$ \\
\hline Formatted & $\ldots[16]$ \\
\hline & \\
\hline Formatted & $\ldots[17]$ \\
\hline Formatted & $\ldots[18]$ \\
\hline Formatted & $\ldots[19]$ \\
\hline Formatted & $\ldots[20]$ \\
\hline & $\ldots[21]$ \\
\hline Formatted & \\
\hline & $\ldots[22]$ \\
\hline
\end{tabular}

\begin{tabular}{|lr|}
\hline Formatted & $\ldots[23]$ \\
\hline Formatted & $\ldots[24]$ \\
\hline Formatted & $\ldots[25]$ \\
\hline & \\
\hline Formatted & $\ldots[26]$ \\
\hline
\end{tabular}

\begin{tabular}{|c|c|}
\hline Formatted & $\ldots[27]$ \\
\hline Formatted & $\ldots[28]$ \\
\hline Formatted & $\ldots[29]$ \\
\hline Formatted & $\ldots[30]$ \\
\hline Formatted & $\ldots[31]$ \\
\hline Formatted & $\ldots[32]$ \\
\hline
\end{tabular}

\begin{tabular}{|lr|}
\hline Formatted & $\ldots[33]$ \\
\hline Formatted & $\ldots[34]$ \\
\hline Formatted & $\ldots[35]$ \\
\hline
\end{tabular}

\begin{tabular}{|lc|}
\hline Formatted & $\ldots[36]$ \\
\hline Formatted & $\ldots[37]$ \\
\hline Formatted & $\ldots[38]$ \\
\hline
\end{tabular}


Malone, T.W. and Crowston, K., 1994. The Interdisciplinary Study of Coordination. ACM Computing Surveys, $26(1), 87-119$.

Malone, T.W., Crowston, K., Lee, J., Pentland, B., Dellarocas, C., Wyner, G., Quimby, J., Osborn, C.S., Bernstein, A., Herman, G., Klein, M. and O'donnell, E., 1999. Tools for inventing organizations: Toward a handbook of organizational processes. Management Science, 45 (3), 425-443.

Mcdermott, J., 1981. R1: The Formative Years. AI Magazine, 2 (2), 21-29.

Molina, A., Rodriguez, C.A., Ahuett, H., Cortés, J.A.,., Ramírez, M., Jiménez, G. and Martinez, S., 2005. Next-generation manufacturing systems: key research issues in developing and integrating reconfigurable and intelligent machines. International Journal of Computer Integrated Manufacturing, 18 (7), 525 - 536.

Møller, C., 2005. ERP II: a conceptual framework for next-generation enterprise systems? Journal of Enterprise Information Management Executive, 18 (4), 483-497.

Oke, A. and Gopalakrishnan, M., 2009. Managing disruptions in supply chains: A case study of a retail supply chain. International Journal of Production Economics, 118 (1), 168-174.

Papazoglou, M.P., Traverso, P., Dustdar, S. and Leymann, F., 2007. Service-Oriented Computing: State of the Art and Research Challenges. IEEE Computer, 40 (11), 64-71.

Pine, B.J., Victor, B. and Boynton, A.C., 1993. Making Mass Customization Work. Harvard Business Review, $71(5), 108-119$.

Porter, M., 1998. Clusters and the New Economics of Competition. Harvard Business Review, 76 (6), 77-90.

Reinhart, G., Wiedemann, M. and Rimpau, C., 2009. An approach for the offer specification process for customised products. International Journal of Computer Integrated Manufacturing, 22 (1), $69-82$.

Rosa, M.L., Lux, J., Seidel, S., Dumas, M. and Hofstede, A.T., 2007. Questionnaire-driven Configuration of Reference Process Models. 19 th International Conference on Advanced

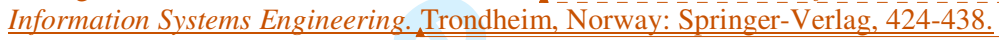

Rosemann, M. and Van Der Aalst, W.M.P., 2007. A configurable reference modelling language. Information Systems, 32 (1), 1-23.

Rupprecht, C., Rose, T., Halm, E.V. and Zwegers, A., 2001. Project-specific Process Configuration in Virtual Enterprises. In: J.P.T. Mo \& L. Nemes, eds. Global Engineering, Manufacturing and Enterprise Networks Norwell/Dordrecht: IFIP / Kluwer Academic Publisher, 46-53.

Sabin, D. and Weigel, R., 1998. Product configuration frameworks - a survey. IEEE Intelligent Systems, $13(4), 42-49$.

Schierholt, K., 2001. Process configuration: Combining the principles of product configuration and process planning. AI-EDAM, 15 (5), 411-424.

Thompson, J.D., 1967. Organization in Action: Social Science Bases of Administrative Theory. NewYork: McGraw-Hill.

Tseng, H.E. and Chen, C.C., 2006. Coordinating product configuration in the order fulfilment processing: an approach based on the binary tree algorithm. International Journal of Computer Integrated Manufacturing, 19 (7), 716 - 726.

Van Aken, J.E., 2004. Management research based on the paradigm of the design sciences: The quest for field-tested and grounded technological rules. Journal of Management Studies, 41 (2), 219-246.

Verdouw, C.N., Beulens, A.J.M., Trienekens, J.H. and Verwaart, D., 2010. Towards dynamic reference information models: Readiness for ICT mass customization. Computers in Industry, in press.

Verwijmeren, M., 2004. Software component architecture in supply chain management. ${ }_{4}$ omputers in Industry, 53 (2), 165-178.

Vorst, J.G.A.J. van der, and Beulens, A.J.M., 2002. Identifying sources of uncertainty to generate supply chain redesign strategies. International Journal of Physical Distribution \& Logistics Management, 32 (6), 409-430.

Wolfert, J., Verdouw, C.N., Verloop, C.M. and Beulens, A.J.M., 2010. Organizing information integration in agri-food: A method based on a service-oriented architecture and living lab approach. Computers and Electronics in Agriculture, in press.

Yin, R.K., 2002. Case Study Research: Design and Methods, Third Edition: Sage Publications.

Zhao, Y. and Fan, Y.S., 2007. Implementation approach of ERP with mass customization. International Journal of Computer Integrated Manufacturing, 20 (2-3), 160-168.

\begin{tabular}{|c|c|}
\hline Formatted & $\ldots[40]$ \\
\hline Formatted & $\ldots[41]$ \\
\hline Formatted & $\ldots$ [42] \\
\hline
\end{tabular}

Formatted $\ldots[43]$

\begin{tabular}{|lr|}
\hline Formatted & $\ldots[44]$ \\
\hline Formatted & \\
\hline Formatted & $\ldots[45]$ \\
\hline Formatted & $\ldots[46]$ \\
\hline
\end{tabular}

Formatted

Formatted

Formatted

Formatted

Formatted

Formatted

Formatted

Zhou, Y. and Chen, Y., 2008. Project-oriented resource assignment: from business process modelling to business process instantiation with operational performance consideration. International Journal of Computer Integrated Manufacturing, 21 (1), 97 - 110.

Formatted

Formatted

Formatted

Formatted

Formatted ... [59]

\begin{tabular}{|lr|}
\hline Formatted & $\ldots[60]$ \\
\hline Formatted & $\ldots[61]$ \\
\hline Formatted & $\ldots[62]$ \\
\hline & \\
\hline Formatted & $\ldots[63]$ \\
\hline
\end{tabular}




\section{Tables}

Table 1. Important configuration-related dependencies of the case company that should be supported
Type (see
Dependencies
figure 1)
1) Product - Possible size of cuttings depends on variety
Assembling - Colour and growing characteristics differ per variety
- Possible tray type depends on variety and maturity
- Applicable category of the royalties depends on variety and customer country
- Product information differs per variety (e.g. growing characteristics) and customer (e.g. barcode) Rules times of order-driven processes (about 14 weeks for seedlings, 5-6 weeks
2) Process - Required delivery time must be equal to or more than the summed lead-
Precedence for rooted cuttings, 10 days for unrooted cuttings)
- Several varieties can only be delivered during a specific season
- Price depends on delivery week because of seasonable production
- Import regulations, including phytosanitary requirements, differ per country
3) Order
Precedence
- Configured order for cuttings triggers configuration of the propagation process
4) Process
Assembling
- Configured order for seedlings determines mixture of seeds to be sourced
- Scope of activities for order fulfilment depend on the extent to which processes are order-driven
- Type of production activities to be configured differs for seedlings and cuttings
- Type of distribution activities to be configured depends on country of destination (for example: road, rail or air freight, and different requirement to shipping documentation).
- Quality control and registration activities depend on required quality management certificate
5) Process
Precedence
6) Product
Precedence
7) Capacity
Precedence
8) Capacity
Rules
Precedence
9) Product
Consumption
10) Capacity Usage
11) Capacity Assembling
- Configured rooting process triggers greenhouse planning \& scheduling
- Transportation activities in the configured process determine types of logistical service provider to be reserved
- Registration activities in the configured process guide data entry
- Seed availability of specific varieties constrains order-driven seeding
- Condition of parent plants determines possibilities for order-driven rooting
- Availability of greenhouse space determines possibilities for configuration of rooting activities in the cuttings order fulfilment
- Availability of air freight capacity constrains configuration of transportation of harvested cuttings
- Location of greenhouse capacity determines location of rooting process
- Availability of educated personnel determines possibility and location of production of unrooted cuttings
- Available parent plants constrains the amount of cuttings that can be harvested
- Available seed constrains the amount of seedlings that can be seeded
- Total greenhouse capacity constrains the amount of cuttings that can be rooted and seedlings that can be budded synchronously, consequently capacity shortage for an urgent order might result in rescheduling another order
- Equipped personnel, machines and greenhouse space must interact effectively to execute configured processes

Formatted

Formatted Table

Deleted: e.g.

Deleted: e.g. 


\section{Figure captions}

Figure 1. Interdependencies for combined product and process configuration

Figure 2. Product configuration in a responsive environment

Figure 3. Illustrative case-firm implementation of product configuration

Deleted: Exemplary

Figure 4. Combined product and process configuration in an agile environment

Figure 5. Illustrative case-firm implementation of process configuration

Deleted: Exemplary 
Page 2: [1] Formatted verdo005

1/8/2010 9:51:00 AM

English (U.K.)

Page 2: [1] Formatted verdo005

1/8/2010 9:51:00 AM

Font: Italic

Page 2: [2] Formatted

verdo005

1/8/2010 9:51:00 AM

Font: Italic, English (U.K.)

Page 2: [2] Formatted verdo005

1/8/2010 9:51:00 AM

English (U.K.)

Page 2: [2] Formatted verdo005

1/8/2010 9:51:00 AM

Font: Italic, English (U.K.)

Page 2: [2] Formatted

English (U.K.) verdo005

verdo005

verdo005

1/8/2010 9:51:00 AM

Page 2: [3] Formatted

verdo005

1/8/2010 9:51:00 AM

Page 2: [3] Formatted

Font: Italic

Page 2: [4] Deleted

verdo005

1/15/2010 2:27:00 PM

(

Page 2: [4] Deleted

verdo005

1/15/2010 2:27:00 PM

Page 2: [5] Formatted

verdo005

1/8/2010 9:51:00 AM

English (U.K.)

Page 2: [5] Formatted

verdo005

1/8/2010 9:51:00 AM

Font: Italic

Page 2: [6] Formatted

verdo005

1/8/2010 9:51:00 AM

English (U.K.)

Page 2: [6] Formatted

verdo005

1/8/2010 9:51:00 AM

English (U.K.)

Page 2: [6] Formatted

verdo005

1/8/2010 9:51:00 AM

English (U.K.)

Page 2: [6] Formatted

verdo005

1/8/2010 9:51:00 AM

English (U.K.)

Page 2: [6] Formatted

verdo005

1/8/2010 9:51:00 AM

English (U.K.) 
Page 2: [6] Formatted verdo005

1/8/2010 9:51:00 AM

English (U.K.)

Page 2: [6] Formatted

verdo005

1/15/2010 12:17:00 PM

Font: Italic

\begin{tabular}{ccc}
\hline $\begin{array}{c}\text { Page 2: [6] Formatted } \\
\text { English (U.K.) }\end{array}$ & verdo005 & 1/8/2010 9:51:00 AM \\
\hline Page 2: [7] Deleted & verdo005 & $1 / 15 / 2010$ 2:02:00 PM \\
( & & \\
\hline Page 2: [7] Deleted & verdo005 & $1 / 15 / 2010$ 2:02:00 PM \\
$\quad$, & & $1 / 8 / 2010$ 9:51:00 AM \\
\hline Page 2: [8] Formatted & verdo005 & \\
\hline English (U.K.) & & $1 / 8 / 2010$ 9:51:00 AM \\
\hline
\end{tabular}

Page 2: [8] Formatted

verdo005

1/8/2010 9:51:00 AM

English (U.K.)

Page 2: [9] Formatted

verdo005

1/8/2010 9:51:00 AM

English (U.K.)

Page 2: [9] Formatted

verdo005

1/8/2010 9:51:00 AM

Font: Italic, English (U.K.)

Page 2: [9] Formatted verdo005

1/8/2010 9:51:00 AM

English (U.K.)

Page 16: [10] Formatted

verdo005

1/8/2010 9:51:00 AM

Font: $10 \mathrm{pt}$

Page 16: [10] Formatted

verdo005

1/8/2010 9:51:00 AM

Font: 10 pt, Italic

Page 16: [10] Formatted

verdo005

1/8/2010 9:51:00 AM

Font: $10 \mathrm{pt}$

Page 16: [11] Formatted

verdo005

1/8/2010 9:51:00 AM

Font: $10 \mathrm{pt}$, Italic

Page 16: [11] Formatted $\quad$ verdo005 $\quad 1 / 8 / 2010$ 9:51:00 AM

Font: $10 \mathrm{pt}$

\section{Page 16: [12] Formatted}

verdo005

1/8/2010 9:51:00 AM

Font: 10 pt, Italic

Page 16: [12] Formatted

verdo005

1/8/2010 9:51:00 AM

Font: $10 \mathrm{pt}$

Page 16: [13] Formatted

verdo005

1/8/2010 9:51:00 AM

Font: 10 pt, Italic 


\section{Page 16: [13] Formatted}

verdo005

1/8/2010 9:51:00 AM

Font: $10 \mathrm{pt}$

Page 16: [14] Formatted

verdo005

1/8/2010 9:51:00 AM

Font: $10 \mathrm{pt}$, Italic

Page 16: [14] Formatted

verdo005

1/8/2010 9:51:00 AM

Font: $10 \mathrm{pt}$

Page 16: [15] Formatted

verdo005

1/8/2010 9:51:00 AM

Font: 10 pt, Italic

Page 16: [15] Formatted

verdo005

1/8/2010 9:51:00 AM

Font: $10 \mathrm{pt}$

Page 16: [16] Formatted

verdo005

1/8/2010 9:51:00 AM

Font: 10 pt, Italic

Page 16: [16] Formatted

verdo005

1/8/2010 9:51:00 AM

Font: $10 \mathrm{pt}$

Page 16: [17] Formatted

verdo005

1/8/2010 9:51:00 AM

Font: 10 pt, Italic

Page 16: [17] Formatted

verdo005

1/8/2010 9:51:00 AM

Font: $10 \mathrm{pt}$

Page 16: [18] Formatted

verdo005

1/8/2010 9:51:00 AM

Font: 10 pt, Italic

Page 16: [18] Formatted

verdo005

1/8/2010 9:51:00 AM

Font: $10 \mathrm{pt}$

Page 16: [19] Formatted

verdo005

1/8/2010 9:51:00 AM

Font: 10 pt, Italic

Page 16: [19] Formatted

verdo005

1/8/2010 9:51:00 AM

Font: $10 \mathrm{pt}$

Page 16: [20] Formatted

verdo005

1/8/2010 9:51:00 AM

Font: $10 \mathrm{pt}$, Italic

Page 16: [20] Formatted

verdo005

1/8/2010 9:51:00 AM

Font: $10 \mathrm{pt}$

Page 16: [21] Formatted

verdo005

1/8/2010 9:51:00 AM

Font: 10 pt, Italic

Page 16: [21] Formatted

verdo005

1/8/2010 9:51:00 AM

Font: $10 \mathrm{pt}$

Page 16: [22] Formatted

verdo005

1/8/2010 9:51:00 AM

Font: 10 pt, Italic 
Page 16: [22] Formatted

verdo005

1/8/2010 9:51:00 AM

Font: $10 \mathrm{pt}$

Page 16: [23] Formatted

verdo005

1/8/2010 9:51:00 AM

Font: $10 \mathrm{pt}$, Italic

Page 16: [23] Formatted

verdo005

1/8/2010 9:51:00 AM

Font: $10 \mathrm{pt}$

Page 16: [24] Formatted

verdo005

1/8/2010 9:51:00 AM

Font: 10 pt, Italic

Page 16: [24] Formatted

verdo005

1/8/2010 9:51:00 AM

Font: $10 \mathrm{pt}$

Page 16: [25] Formatted

verdo005

1/8/2010 9:51:00 AM

Font: 10 pt, Italic

Page 16: [25] Formatted

verdo005

1/8/2010 9:51:00 AM

Font: $10 \mathrm{pt}$

Page 16: [26] Formatted

verdo005

1/8/2010 9:51:00 AM

Font: $10 \mathrm{pt}$, Italic

Page 16: [26] Formatted

verdo005

1/8/2010 9:51:00 AM

Font: $10 \mathrm{pt}$

Page 16: [27] Formatted

verdo005

1/8/2010 9:51:00 AM

Font: 10 pt, Italic

Page 16: [27] Formatted

verdo005

1/8/2010 9:51:00 AM

Font: $10 \mathrm{pt}$

Page 16: [28] Formatted

verdo005

1/8/2010 9:51:00 AM

Font: 10 pt, Italic

Page 16: [28] Formatted

verdo005

1/8/2010 9:51:00 AM

Font: $10 \mathrm{pt}$

Page 16: [29] Formatted

verdo005

1/8/2010 9:51:00 AM

Font: $10 \mathrm{pt}$, Italic

$\begin{array}{lll}\text { Page 16: [29] Formatted } & \text { verdo005 } & 1 / 8 / 2010 \text { 9:51:00 AM }\end{array}$

Font: $10 \mathrm{pt}$

\section{Page 16: [30] Formatted}

verdo005

1/8/2010 9:51:00 AM

Font: 10 pt, Italic

Page 16: [30] Formatted

verdo005

1/8/2010 9:51:00 AM

Font: $10 \mathrm{pt}$

Page 16: [31] Formatted

verdo005

1/8/2010 9:51:00 AM

Font: 10 pt, Italic 


\section{Page 16: [31] Formatted}

verdo005

1/8/2010 9:51:00 AM

Font: $10 \mathrm{pt}$

Page 16: [32] Formatted

verdo005

1/8/2010 9:51:00 AM

Font: $10 \mathrm{pt}$, Italic

Page 16: [32] Formatted

verdo005

1/8/2010 9:51:00 AM

Font: $10 \mathrm{pt}$

Page 16: [33] Formatted

verdo005

1/8/2010 9:51:00 AM

Font: 10 pt, Italic

Page 16: [33] Formatted

verdo005

1/8/2010 9:51:00 AM

Font: $10 \mathrm{pt}$

Page 16: [34] Formatted

verdo005

1/8/2010 9:51:00 AM

Font: 10 pt, Italic

Page 16: [34] Formatted

verdo005

1/8/2010 9:51:00 AM

Font: $10 \mathrm{pt}$

Page 16: [35] Formatted

verdo005

1/8/2010 9:51:00 AM

Font: $10 \mathrm{pt}$, Italic

Page 16: [35] Formatted

verdo005

1/8/2010 9:51:00 AM

Font: $10 \mathrm{pt}$

Page 16: [36] Formatted

verdo005

1/8/2010 9:51:00 AM

Font: 10 pt, Italic

Page 16: [36] Formatted

verdo005

1/8/2010 9:51:00 AM

Font: $10 \mathrm{pt}$

Page 16: [37] Formatted

verdo005

1/8/2010 9:51:00 AM

Font: 10 pt, Italic

Page 16: [37] Formatted

verdo005

1/8/2010 9:51:00 AM

Font: $10 \mathrm{pt}$

Page 16: [38] Formatted

verdo005

1/8/2010 9:51:00 AM

Font: $10 \mathrm{pt}$, Italic

$\begin{array}{lll}\text { Page 16: [38] Formatted } & \text { verdo005 } & 1 / 8 / 2010 \text { 9:51:00 AM }\end{array}$

Font: $10 \mathrm{pt}$

\section{Page 17: [39] Formatted}

verdo005

1/8/2010 9:51:00 AM

Font: 10 pt, Italic

Page 17: [39] Formatted

Font: $10 \mathrm{pt}$ verdo005

1/8/2010 9:51:00 AM

verdo005

1/8/2010 9:51:00 AM

Font: $10 \mathrm{pt}$, Italic 
Page 17: [40] Formatted

verdo005

1/8/2010 9:51:00 AM

Font: $10 \mathrm{pt}$

Page 17: [41] Formatted

verdo005

1/8/2010 9:51:00 AM

Font: 10 pt, Italic

Page 17: [41] Formatted

verdo005

1/8/2010 9:51:00 AM

Font: $10 \mathrm{pt}$

Page 17: [42] Formatted

verdo005

1/15/2010 3:28:00 PM

Font: 10 pt, Spanish (Spain-Modern Sort)

Page 17: [42] Formatted verdo005

1/8/2010 9:51:00 AM

Font: $10 \mathrm{pt}$

Page 17: [42] Formatted

verdo005

1/8/2010 9:51:00 AM

Font: 10 pt, Italic

Page 17: [42] Formatted

verdo005

1/8/2010 9:51:00 AM

Font: $10 \mathrm{pt}$

Page 17: [43] Formatted

verdo005

1/8/2010 9:51:00 AM

Font: $10 \mathrm{pt}$, Italic

Page 17: [43] Formatted

verdo005

1/8/2010 9:51:00 AM

Font: $10 \mathrm{pt}$

\section{Page 17: [44] Formatted}

verdo005

1/8/2010 9:51:00 AM

Font: 10 pt, Italic

Page 17: [44] Formatted

verdo005

1/8/2010 9:51:00 AM

Font: $10 \mathrm{pt}$

Page 17: [45] Formatted

verdo005

1/8/2010 9:51:00 AM

Font: 10 pt, Italic

$$
\text { Page 17: [45] Formatted }
$$

verdo005

1/8/2010 9:51:00 AM

Font: $10 \mathrm{pt}$

Page 17: [46] Formatted

verdo005

1/8/2010 9:51:00 AM

Font: $10 \mathrm{pt}$, Italic

$\begin{array}{lll}\text { Page 17: [46] Formatted } & \text { verdo005 } & 1 / 8 / 2010 \text { 9:51:00 AM }\end{array}$

Font: $10 \mathrm{pt}$

\section{Page 17: [47] Formatted}

verdo005

1/8/2010 9:51:00 AM

Font: 10 pt, Italic

Page 17: [47] Formatted

Font: $10 \mathrm{pt}$ verdo005

1/8/2010 9:51:00 AM

verdo005

1/8/2010 9:51:00 AM

Font: $10 \mathrm{pt}$, Italic 


\section{Page 17: [48] Formatted}

verdo005

1/8/2010 9:51:00 AM

Font: $10 \mathrm{pt}$

Page 17: [49] Formatted

verdo005

1/8/2010 9:51:00 AM

Font: $10 \mathrm{pt}$, Italic

Page 17: [49] Formatted

verdo005

1/8/2010 9:51:00 AM

Font: $10 \mathrm{pt}$

Page 17: [50] Formatted

verdo005

1/8/2010 9:51:00 AM

Font: 10 pt, Italic

Page 17: [50] Formatted

verdo005

1/8/2010 9:51:00 AM

Font: $10 \mathrm{pt}$

Page 17: [51] Formatted

verdo005

1/15/2010 3:28:00 PM

Font: 10 pt, German (Germany)

Page 17: [51] Formatted

verdo005

1/8/2010 9:51:00 AM

Font: $10 \mathrm{pt}$

Page 17: [51] Formatted

verdo005

1/8/2010 9:51:00 AM

Font: 10 pt, Italic

Page 17: [51] Formatted

verdo005

1/8/2010 9:51:00 AM

Font: $10 \mathrm{pt}$

\section{Page 17: [51] Formatted}

$$
\text { verdo005 }
$$

1/8/2010 9:51:00 AM

Font: 10 pt, Italic

Page 17: [51] Formatted

verdo005

1/8/2010 9:51:00 AM

Font: $10 \mathrm{pt}$

Page 17: [52] Formatted

verdo005

1/15/2010 3:28:00 PM

Font: 10 pt, German (Germany)

Page 17: [52] Formatted verdo005

1/8/2010 9:51:00 AM

Font: $10 \mathrm{pt}$

Page 17: [52] Formatted

verdo005

1/8/2010 9:51:00 AM

Font: 10 pt, Italic

Page 17: [52] Formatted $\quad$ verdo005 $\quad 1 / 8 / 2010$ 9:51:00 AM

Font: $10 \mathrm{pt}$

\section{Page 17: [53] Formatted}

verdo005

1/8/2010 9:51:00 AM

Font: 10 pt, Italic

Page 17: [53] Formatted

verdo005

1/8/2010 9:51:00 AM

Font: $10 \mathrm{pt}$

Page 17: [54] Formatted

verdo005

1/8/2010 9:51:00 AM

Font: 10 pt, Italic 


\section{Page 17: [54] Formatted}

verdo005

1/8/2010 9:51:00 AM

Font: $10 \mathrm{pt}$

Page 17: [55] Formatted

verdo005

1/8/2010 9:51:00 AM

Font: $10 \mathrm{pt}$, Italic

Page 17: [55] Formatted

verdo005

1/8/2010 9:51:00 AM

Font: $10 \mathrm{pt}$

Page 17: [56] Formatted

verdo005

1/8/2010 9:51:00 AM

Font: 10 pt, Italic

Page 17: [56] Formatted

verdo005

1/8/2010 9:51:00 AM

Font: $10 \mathrm{pt}$

Page 17: [57] Formatted

verdo005

1/8/2010 9:51:00 AM

Font: 10 pt, Italic

Page 17: [57] Formatted

verdo005

1/8/2010 9:51:00 AM

Font: $10 \mathrm{pt}$

Page 17: [58] Formatted

verdo005

1/8/2010 9:51:00 AM

Font: 10 pt, Italic

Page 17: [58] Formatted

verdo005

1/15/2010 1:57:00 PM

Font: $10 \mathrm{pt}$

Page 17: [59] Formatted

verdo005

1/15/2010 3:28:00 PM

Font: 10 pt, English (U.S.)

Page 17: [59] Formatted

verdo005

1/15/2010 3:28:00 PM

English (U.S.)

Page 17: [59] Formatted

verdo005

1/15/2010 3:28:00 PM

Font: 10 pt, English (U.S.)

Page 17: [59] Formatted

verdo005

1/15/2010 1:57:00 PM

Font: $10 \mathrm{pt}$

Page 17: [59] Formatted

verdo005

1/15/2010 1:57:00 PM

Font: 10 pt, Not Italic

Page 17: [59] Formatted

verdo005

1/15/2010 1:57:00 PM

Font: $10 \mathrm{pt}$

Page 17: [60] Formatted

verdo005

1/8/2010 9:51:00 AM

Font: 10 pt, Italic

Page 17: [60] Formatted

verdo005

1/8/2010 9:51:00 AM

Font: $10 \mathrm{pt}$

Page 17: [61] Formatted

verdo005

1/8/2010 9:51:00 AM

Font: $10 \mathrm{pt}$, Italic 
Page 17: [61] Formatted

Font: $10 \mathrm{pt}$ verdo005

verdo005

verdo005

1/8/2010 9:51:00 AM

Font: 10 pt, Italic

Page 17: [62] Formatted

Font: $10 \mathrm{pt}$

Page 17: [63] Formatted

verdo005

1/8/2010 9:51:00 AM

Font: 10 pt, Italic

Page 17: [63] Formatted

verdo005

1/8/2010 9:51:00 AM

Font: $10 \mathrm{pt}$ 


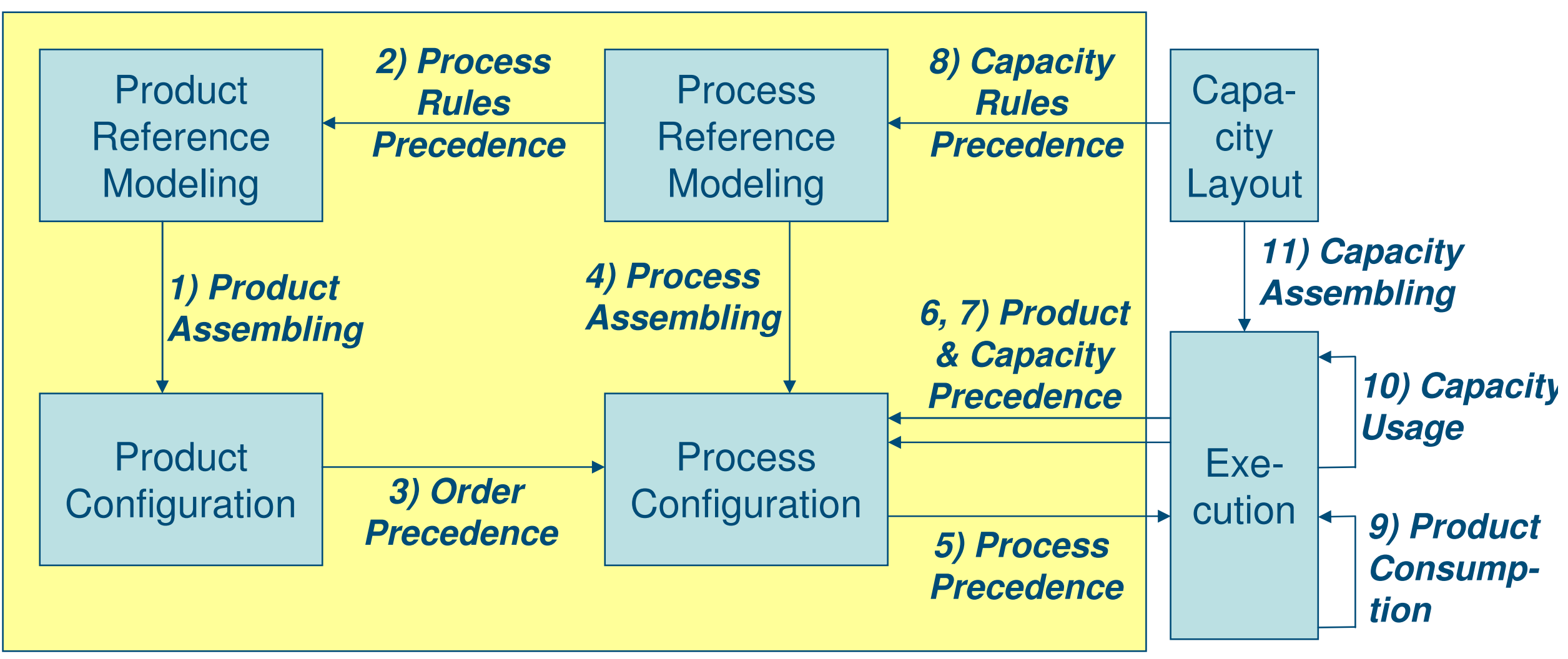




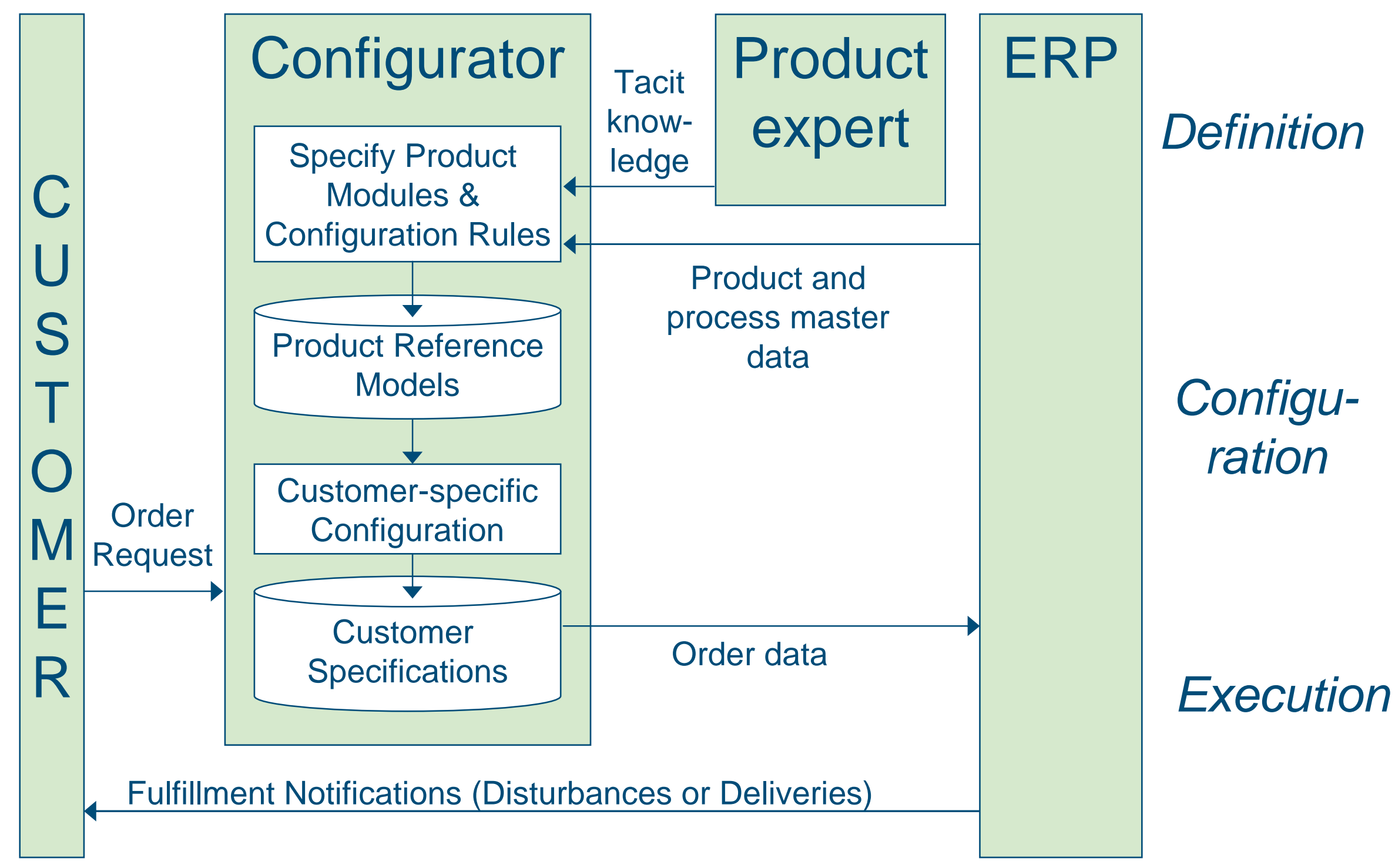




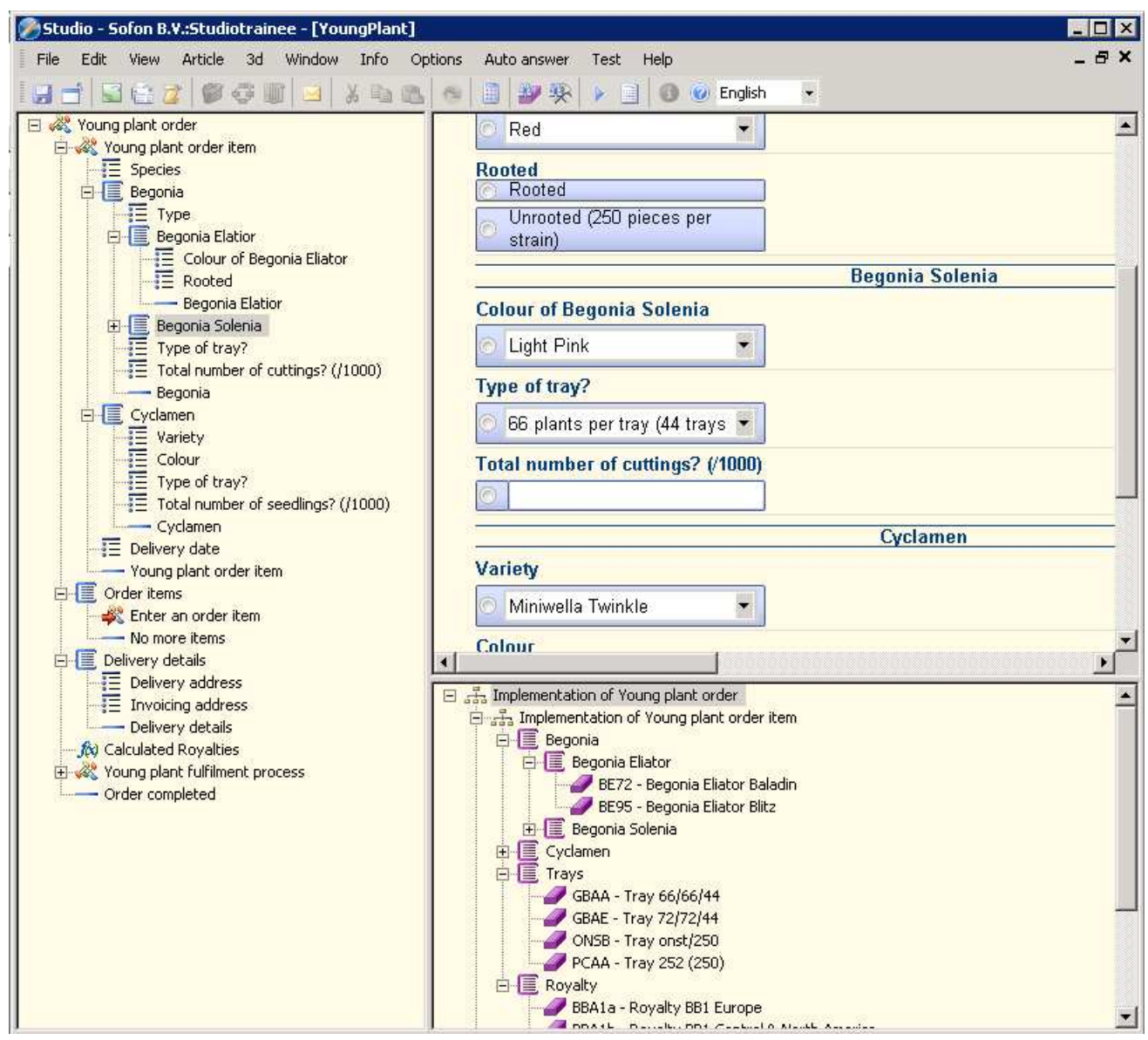

Figure 3. Illustrative case-firm implementation of product configuration 


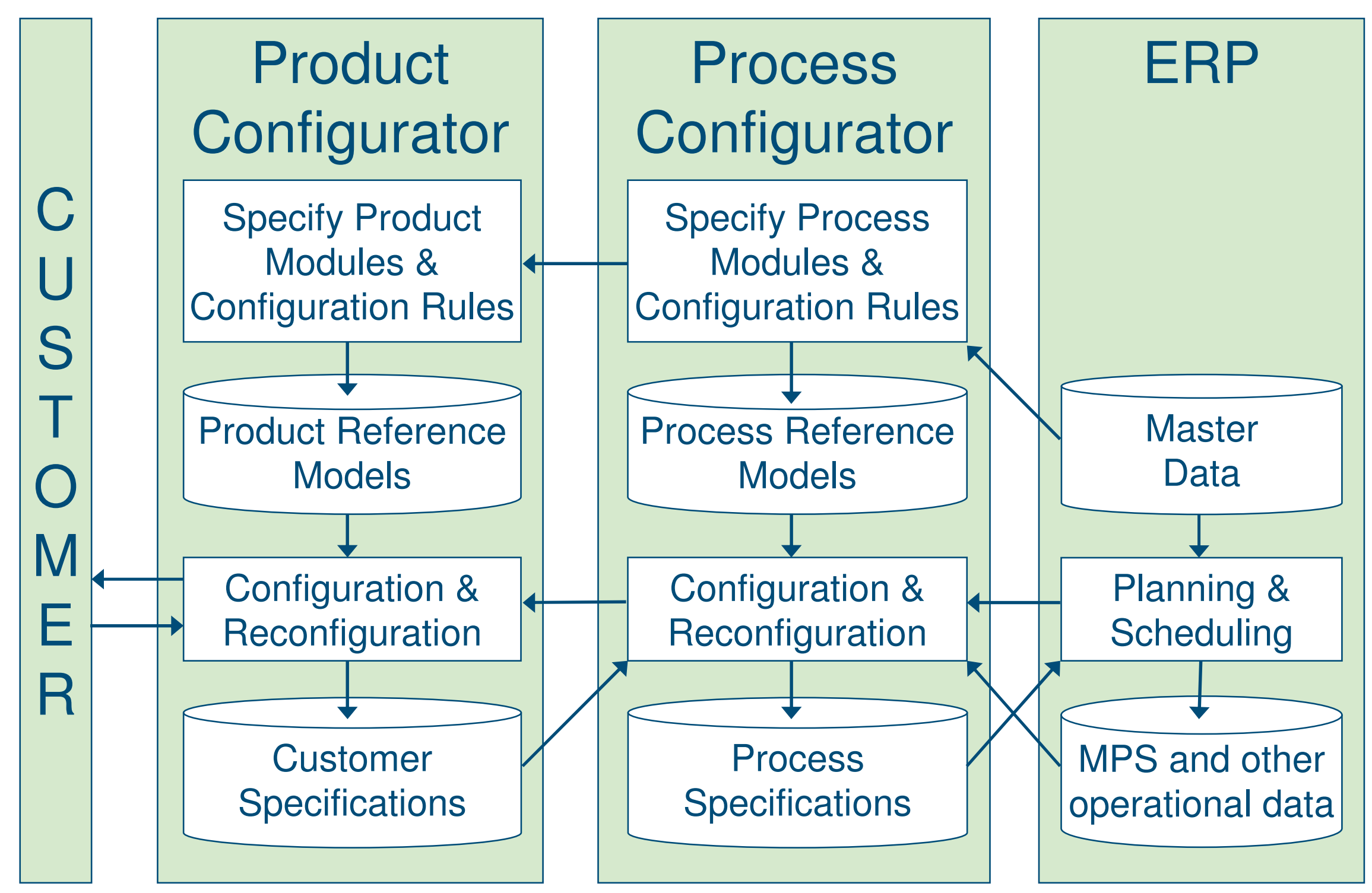




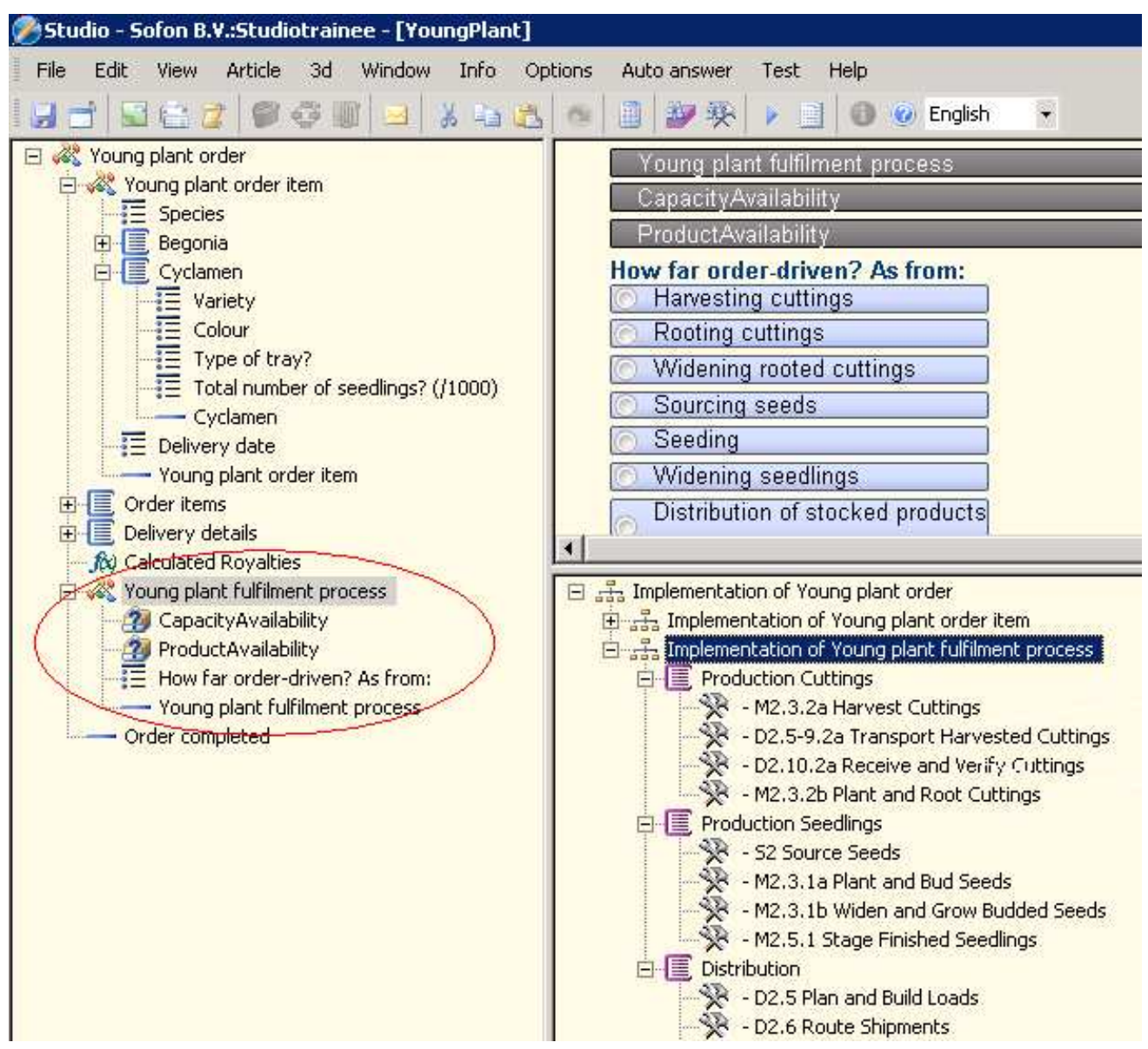

Figure 5. Illustrative case-firm implementation of process configuration 